\title{
Word Learning according to Stimulus Conditions of Korean Children with Specific Language Impairment
}

\author{
Ji Won An ${ }^{a}$, Hee Ran Lee ${ }^{\mathrm{b}}$ \\ ${ }^{a}$ Department of Speech and Hearing Therapy, Graduate School of Catholic University of Pusan, Busan, Korea \\ ${ }^{b}$ Department of Speech and Hearing Therapy, Catholic University of Pusan, Busan, Korea
}

\author{
Correspondence: Hee Ran Lee, $\mathrm{PhD}$ \\ Department of Speech and Hearing Therapy, \\ Catholic University of Pusan, 57 Oryundae-ro, \\ Geumjeong-gu, Busan 46252, Korea \\ Tel: +82-51-510-0841 \\ Fax: +82-51-510-0848 \\ E-mail: hrlee@cup.ac.kr \\ Received: January 5, 2018 \\ Revised: February 6, 2018 \\ Accepted: February 14, 2018
}

This work is based on a part of the first author's master's thesis from Catholic University of Pusan.
Objectives: The purpose of this study was to examine the effects of stimulus conditions, such as category, shape, and theme, as children with specific language impairment (SLI) learned new words. Methods: Seventeen children (aged 4-6 years) in a SLI group, 17 in a chronological age-matched children (CA) group, and 17 in a language age-matched children (LA) group participated in the study. The stimulus conditions were a total of 22 sets, which consisted of one standard stimulus and three stimulus conditions for the children to choose (including exercise questions). The stimulus conditions consisted of category stimuli, shape stimuli, and thematic stimuli. Results: First, there were significant differences between the SLI and CA groups, and the SLI and LA groups, in category and shape stimuli. However, there was a significant difference only between the SLI and CA groups in thematic stimuli. Second, the groups exhibited higher to lower word meaning interference across conditions as follows: SLI (shape stimuli > category stimuli > thematic stimuli), CA (category stimuli > thematic stimuli > shape stimuli), and LA (category stimuli > shape stimuli > thematic stimuli). Conclusion: Children with SLI respond based on shape similarity when they infer the meaning of words, but typically developing children focus on categorization. This implies the mechanism for word learning is different for children with SLI. Thus, this study has its clinical significance in suggesting a basis for understanding the semantic knowledge of the subjects and the necessity of higher level categorization knowledge to understand the characteristics of word acquisition of children with SLI and to provide better intervention methods for them.

Keywords: Specific language impairment (SLI), Word learning, Inference, Category, Shape, Thematic
아동은 초기 단어 습득 과정에서 새로운 단어를 들었을 때 연속 적인 말의 흐름에서 단어의 뜻을 찾고, 대상과 단어의 의미를 연결 한다. 이와 같이 아동의 단어 습득은 맥락으로부터 새로운 단어의 의미를 추론하고 음운 형태를 저장하는 것으로부터 시작된다(Ludden, 2015). 또한, 발화가 이루어진 자연스러운 환경 맥락 내에 존재 하는 의미적 단서(semantic cue)와 구문적 단서(syntactic cue)를 조 합하여 해당 낱말의 의미를 추론하고 이해하는 과정을 통하여 초 기에 습득해야 할 대부분의 단어들을 습득하게 된다(Rice, 1990). 단순언어장애 아동들은 12 개월경에 첫 낱말을 산출하는 일반 아 동과 달리 초기 단어 습득이 지체되어 있고 이후 어휘발달에서도
또래 아동들에 비해 습득한 어휘의 양이 적고 어휘 사용 능력이 낮 으며, 초기 단어 습득 과정에 중요하게 작용하는 빠른 연결하기(fastmapping)와 더불어 특정 낱말을 산출하는 데서도 어려움을 보인 다(Jackson, Leitao, \& Claessen, 2015; Lee, 2005; Leonard, 2014; Rice, Buhr, \& Oetting, 1992). 또한 이들은 단어 습득 능력의 결함 뿐만 아니라 의미론 및 구문론적 결함 등과 같은 언어의 전반적인 측면에서 결함을 가지고 있다. 학령기가 되면 이러한 의미론적 결 함과 더불어 관련 언어결함들이 읽기장애로 발전할 수 있는 위험 이 있다는 연구 결과들이 제시되고 있기도 하다(Isoaho, Kauppila, \& Launonen, 2016; Whitehouse, Line, Watt, \& Bishop, 2009). 
단순언어장애 아동들의 어휘결함은 많은 연구들에서 다양한 측 면으로 설명되어 왔다. Rice, Cleave와 Oetting (2000)은 학령전 단 순언어장애 아동들의 어휘결함을 새로운 낱말의 빠른우연학습능 력(QUIL)에서의 결함으로 설명한 반면, Lee (2005)는 의미적으로 관계된 개념 또는 정보들과 연결지어가며 다양한 분류적 체계에 따라 낱말을 분류해가는 과정인 의미구조화의 취약함이 학령전 단순언어장애 아동들의 어휘 습득 및 사용과 밀접한 관련이 있음 을 보고하였다. 또한 $\operatorname{Kim}$ (2004)은 이들이 일반 아동에 비해 작업 기억 능력이 부족하며, 이러한 작업기억 결함은 단순언어장애 아동 의 어휘 습득의 어려움과 관련성이 있음을 밝혔다. 작업기억은 짧 은 기간 동안 정보를 유지하고 조작하는 능력으로, 작업기억의 개 인차는 지식 및 새로운 기술의 획득, 읽기, 계산, 언어 이해 등, 광범 위한 고등 인지기능과 관련되어 있음이 많은 연구들에 의해서 밝 혀져 왔다. 특히, 작업기억과 더불어 대상과 공간, 그리고 언어양식 으로 구분되는 인지양식은 작업기억의 개인차를 결정짓는 요인으 로 제기되기도 했다(Shin \& Kim, 2013). 단순언어장애는 진단 기준 에서 이미 지능에 결함이 없음을 가정하고 있지만, 이들이 전형적 으로 발달하는 아동과는 다른 인지양식을 갖는지의 문제는 이들 의 언어결함을 설명하는 매우 중요한 단서가 될 수 있을 것으로 보 인다. 즉, 단순언어장애 아동들의 언어결함은 장기기억에 저장된 단어의 양적 부족에서 기인할 수 있으며, 이러한 저장의 문제는 결 국 어휘집에 있는 이들 단어들의 이해 및 표현결함으로 이어질 수 있을 것이다.

몇몇 연구자들은 낱말정의, 전제의미 판단, 의미점화 과제 등을 이용하여 단순언어장애 아동들이 보이는 의미론적 결함에 대한 근 본 기제를 설명하기 위한 연구를 진행하였다(Kim et al., 2012; Lee \& Kim, 2003; Lee \& Lee, 2006; Marinellie \& Johnson, 2002; McGregor \& Appel, 2002). 무엇보다 단순언어장애 아동들이 일반 아 동과 비교적 유사한 방식으로 단어의 의미를 이해하거나 의미론 지 식을 습득할 수 있음이 보고된 바 있다(Botting \& Adams, 2005; Gray, 2005). Gray (2005)는 단순언어장애 아동 역시 단어 습득 과정 에서 특정 단서가 제공될 경우, 즉 대상의 상위 개념과 물리적인 특 성, 그리고 연관성과 같은 의미적 단서가 있는 조건에서 단어를 이해 하고, 단어의 첫 소리, 첫 음절과 같은 음운적 단서가 있는 조건에서 단어를 표현하는 것이 향상되었다고 보고하였다. 또한 Lee와 Lee (2000)는 단순언어장애 아동들도 적절한 단어 습득 전략을 사용하 면 단어 습득을 보다 용이하게 할 수 있음을 밝히고 있기도 하다.

아동의 초기 의미론 발달 과정에서 새로운 단어 의미를 습득하고 추론하는 것은 중요한 의미를 지니며 아동의 언어발달에도 영향을 준다(Bloom, 2001; Sobel, Sedivy, Buchanan, \& Hennessy, 2012). 특
히, 단어가 갖는 여러 지각적이고 맥락적인 특성들은 단어의미 추 론에 매우 중요하게 작용한다고 볼 수 있다(Imai, Gentner, \& Uchida, 1994; Kim \& Lee, 1996; Saalbach \& Schalk, 2011). 우선, Imai 등 (1994)은 단어의미 추론 과정에서 범주적 자극, 지각적 유사성, 주 제적 자극을 비교하여 아동들이 표본 자극의 어떤 자극 조건에 의 해 영향을 받는지 살펴보았다. 그 결과, 3 세와 5 세 아동들은 새로운 단어가 주어졌을 때 범주적인 자극보다는 지각적 유사성에 반응하 였다. 반면, 성인들은 새로운 단어가 주어졌을 때 지각적 유사성보 다는 범주적 자극에 반응을 하였다. 또한 3 세와 비교했을 때 5세 아동들은 지각적 유사성에 대한 반응이 점점 감소하고 범주적 자 극에 대한 반응이 증가했음을 볼 수 있었다. 이러한 결과를 통해 가 정해볼 때, 연구자들은 새로운 단어의 의미를 추론할 때 형태에 근 거한 반응에서 범주에 근거한 반응으로 발달적 변화가 일어난 것 을 '형태로부터 범주로의 전환(shape-to-taxonomic shift)’이라고 지칭하였다. 이는 아동이 새로운 단어 습득의 초기 단계에서는 형 태적 유사성에 기반하여 단어를 습득하지만 아동이 점차 발달하 면서 범주적인 관계로 연관 지어 단어를 습득한다는 것을 말한다. 따라서, 어린 아동의 경우 범주적인 관계보다는 지각적 유사성에 초점을 두지만 점차 지각적 유사성을 능가하여 범주적인 관계의 개 념도 스스로 인식할 수 있게 된다는 것으로 해석할 수 있다. 이와 더 불어, Golinkoff, Shuff-Bailey, Olguin과 Ruan (1995)은 18-36개월 아동들이 지각적으로 유사한 자극과 주제적으로 관련 있는 자극 중 어느 것을 선호하는지 살펴보았다. 그 결과, 20 개월 아동들은 대 상의 기본 범주보다는 지각적 유사성을 선호하는 경향을 보였으나, 34 개월 아동들은 기본 범주의 분류 관계에 기초해서 새로운 단어 를 추론할 수 있었다. 또한 27 개월 아동들 역시 34 개월 아동들만큼 은 아니더라도 기본 범주에 대한 반응을 하였다.

특히, Saalbach와 Schalk (2011)는 3세 아동과 성인이 새로운 대 상으로 단어의미를 확장하기 위해서 범주, 형태, 그리고 주제적 관 계에 어떻게 반응하는지를 살펴보았다. 연구 결과, 3 세 아동이 형태 에 기반한 전략을 주로 사용하지만 성인처럼 범주적 관계에 대한 지식도 가지고 있는 것으로 나타났다. 즉, 3 세 아동이 성인과 마찬 가지로 범주를 기반으로 단어 확장 전략을 사용할 수 있다는 것을 확인하였다. 반면, Collisson, Grela, Spaulding, Rueckl과 Magnu$\operatorname{son}$ (2015)은 5세 단순언어장애 아동들의 경우에는 또래와 비교할 때 형태에 기반한 단어의미 추론에도 여전히 취약함을 보여준다고 밝히고 있다. 연구자들에 따르면, 형태 편파 민감성을 살펴보기 위 해 형태, 색깔, 재질 단서를 이용해 3 차원의 새로운 대상에 대한 단 어의미 확장 과제를 실시했을 때, 과제의 어려움이 있었겠지만 일 반 아동들이 3 세 수준에 적용하는 형태 기반 전략을 단순언어장애 
아동은 5 세에 이르러서도 적용하는 데 여전히 어려움이 있었다고 보고하였다.

단어 습득 과정에서 자극조건이 미치는 영향과 관련해 이루어진 국내연구로, Kim과 Lee (1996)는 3세, 5세, 7세 아동과 성인을 대상 으로 범주적 자극과 형태적 자극, 그리고 주제적 자극이 주어졌을 때 새로운 단어를 어느 자극에서 일반화시키는지 살펴보고, 연령 에 따라 새로운 단어를 추론하는 것이 변화하는지 살펴보고자 하 였다. 그 결과, 새로운 단어를 습득할 때 3 세와 5 세 아동들은 범주 적 자극보다는 형태에 대한 강한 편중성을 보였으나, 7세 아동들은 형태적 자극에 대한 반응이 점차 감소하고 범주적 자극에 대한 반 응이 증가하였다. 아동들과는 반대로 성인들은 형태와 같은 지각적 유사성보다 범주적 자극에 기반하여 반응하는 것으로 나타났다.

$\operatorname{Kim}$ (2007)은 3세, 5세, 7세, 9세 아동을 대상으로 분류적 범주 화와 주제적 범주화의 수준을 측정하여 연령이 높아질수록 범주 화의 양상이 어떻게 변화하는지 살펴보았다. 연구 결과, 3 세와 5 세, 7세 아동이 분류적 범주화보다 주제적 범주화를 먼저 습득하게 되 고 이후 분류적 범주화의 발달이 두드러지게 나타나는 양상을 확 인하였다. 이는 학령전 아동들이 단어를 접하고 의미를 파악할 때 대상이나 사물을 분류하여 범주화하는 것보다 대상 간의 상호작 용적 관계와 보완적 관계를 더 선호한다는 것으로 볼 수 있다.

위에서 살펴본 바와 같이, 단순언어장애 아동이 또래 아동에 비 해 새로운 단어 습득 속도가 느리다는 것은 분명하므로, 이들의 단 어 습득 기제를 밝힘과 동시에 이후 단어 습득을 촉진하기 위한 변 별적인 진단과 중재가 필요할 것이다. 즉, 단순언어장애 아동의 단 어 습득을 촉진하기 위해서는 이들이 초기 의미론 발달 과정에서 새로운 단어의 의미를 습득하고 추론하는 특성이 일반 아동들과 어떻게 다른지 파악하는 것이 중요하다. 여러 선행연구들은 학령전 아동들이 새로운 단어를 습득하고 의미를 확장할 때 범주와 형태, 그리고 주제라는 자극 조건에 따라 발달적인 변화가 나타나고 있 음을 보고하고 있다.

따라서, 본 연구에서는 단순언어장애 아동의 새로운 단어 습득 과정에서 범주, 형태, 그리고 주제라는 자극 조건이 이들이 단어의 의미를 추론하는 데 어떠한 영향을 미치는지 살펴보고자 하였다.

\section{연구방법}

\section{연구대상}

본 연구는 부산시에 거주하는 4-6세 단순언어장애 아동 17명과 생활연령일치 아동 17 명, 언어연령일치 아동 17 명, 총 51 명을 대상 으로 하였다. 일반 아동의 초기 단어의미 추론 연구가 대체로 3 세
를 기준으로 진행되는 것과 대비해, 5 세경의 단순언어장애 아동의 산출 언어는 3 세 아동 수준인 것으로 보고되고 있으며, 선행연구의 연령 기준을 참조하여 4-6세 연령의 아동을 대상으로 연구를 진행 하였다(Lee \& Ha, 2015; Lee \& Kim, 2003).

단순언어장애 아동 집단은 Stark와 Tallal (1981)과 Lee와 Kim (2003)의 기준을 참조하여 (1) 취학전 아동의 수용언어 및 표현언어 척도(Preschool Receptive-Expressive Language Scale, PRES; Kim, Sung, \& Lee, 2003) 검사 결과, 생활연령과 비교하여 수용언어는 6 개월, 표현언어는 1년 이상 지체되고, (2) 한국 웩슬러 유아지능검 사(Korean Wechsler Preschool and Primary Scale of Intelligence, K-WPPSI; Park, Kwak, \& Park, 1997) 결과, 동작성 지능이 85 이상 이며, (3) 부모나 교사에 의해 시각 및 청각과 같은 감각 장애와 정 서 및 행동문제가 없다고 보고된 아동을 대상으로 선정하였다.

생활연령일치 아동 집단은 (1) 부모나 교사에 의해 언어 및 기타 발달에 문제가 없는 것으로 보고되고, (2) 취학전 아동의 수용언어 및 표현언어 척도(PRES; Kim et al., 2003) 검사 결과, 통합언어연령 이 자신의 생활연령에 비교하여 1년 이상 지체되지 않고, (3) 한국 웩슬러 유아지능검사(K-WPPSI; Park et al., 1997) 결과, 동작성 지 능이 85 이상이며, (4) 단순언어장애 아동들과 일대일로 대응시켰 을 때 생활연령이 \pm 3 개월 이내에 속하는 아동을 대상으로 선정하 였다.

언어연령일치 아동 집단은 (1) 부모나 교사에 의해 언어 및 그 외 발달에 문제가 없는 것으로 보고되고, (2) 취학전 아동의 수용언어 및 표현언어 척도(PRES; Kim et al., 2003) 검사 결과, 단순언어장애 집단과 일대일로 대응시켰을 때 통합언어연령이 \pm 3 개월 이내에 속하며, (3) 한국 웩슬러 유아지능검사(K-WPPSI; Park et al., 1997) 결과, 동작성 지능이 85 이상인 아동을 대상으로 선정하였다(Table 1). 단순언어장애 아동 집단의 생활연령은 평균 5 세 8 개월(4세 3 개 월-6세 5 개월)이었으며, 생활연령일치 아동 집단의 생활연령도 평 균 5 세 8 개월(4세 10 개월-6세 7 개월)이었다. 집단에 대한 연령의 통 제가 잘 이루어졌는지 확인하기 위해 집단 간 $t$-검정을 실시한 결과,

Table 1. Characteristics of participants

\begin{tabular}{lccc}
\hline & SLI group (N=17) & CA group (N=17) & LA group (N=17) \\
\hline Age (mo) & $68.00(8.52)$ & $68.18(7.34)$ & $52.76(6.04)$ \\
Nonverbal IO $^{\mathrm{a}}$ & $95.88(8.29)$ & $107.18(15.82)$ & $103.59(13.57)$ \\
Language age $^{\mathrm{b}}$ & $51.64(8.17)$ & $68.47(7.92)$ & $52.61(5.80)$ \\
\hline
\end{tabular}

Values are presented as mean (SD).

$S L I=$ children with specific language impairment; $C A=$ chronological age-matched children; $\mathrm{LA}=$ language age-matched children.

aKorean-Wechsler Preschool and Primary Scale of Intelligence (Park, Kwak, \& Park, 1997).

'Preschool Receptive-Expressive Language Scale (Kim, Sung, \& Lee, 2003). 
단순언어장애 아동 집단과 생활연령일치 아동 집단 간에 생활연령 에 따른 유의한 차이가 없는 것으로 나타났다 $(t=-.07, p>.05)$. 또한 단순언어장애 아동 집단의 언어연령은 평균 4 세 3 개월(3세 4 개월-5 세 6개월)이었으며, 언어연령일치 아동 집단의 언어연령은 평균 4 세 4 개월(3세 7 개월-5세 1 개월)이었다. 집단 간 $t$-검정을 실시한 결과, 단순언어장애 아동 집단과 언어연령일치 아동 집단 간에 언어연령 에 따른 유의한 차이가 없는 것으로 나타났다 $(t=-.40, p>.05)$. 그 외 동작성 지능에서도 집단 간에 유의한 차이가 없는 것으로 나타 났다 $\left(F_{(2,48)}=3.395, p>.05\right)$.

\section{연구도구}

자극 조건 과제

본 연구에서는 아동이 새로운 단어의 의미를 추론할 때 어떠한 자극 조건이 영향을 주는지 확인하기 위해 과제를 실시하였다. 먼 저, 아동에게 제시되는 표본 자극은 비단어와 그에 해당하는 그림 으로 구성하였으며, 아동이 선택해야 하는 자극 조건은 범주, 형태, 주제의 세 가지 유형의 그림이었다.

과제에 사용된 어휘는 Kim (2001), Lee와 Kim (2003), Lee, Chang, Choi와 Lee (2009), Cha, Kim, Kim, Yoon과 Chang (2014), 그림은 Kim과 Lee (1996), Imai 등(1994), Saalbach와 Schalk (2011)의 연구 를 참고하여, 연구대상 아동들에게 적합하도록 수정해서 사용하 였다. 특히 표본 자극의 어휘는 범주화 과제(Kim, 2007)를 사용하 여 아동들에게 친숙한 의미범주(과일 및 채소, 동물, 사물)로 구성 하였다.

표본 자극의 비단어는 연구대상 아동들이 이전에 들어본 경험 이 없는 무의미 음절로 제작하였다. 비단어의 발음에 다른 난이도 가 아동들의 단어의미 추론에 미치는 영향을 최소화하기 위하여 비단어는 24-30개월 일반 아동의 산출 비율이 낮은 자음 유형인 /ㅈ, ㅊ, ㅉ, ㅅ, 씨, 히을 제외하고, 나머지 자음과 모음/F, ㄱ, ㄴ, T, 一, 1, ㅐㅐㄹㅗ 조합하여 단순한 음운구조를 가지는 2 음절의 단 어 22개를 제작하였다(Jung, Pae, \& Kim, 2006; Sim \& Ha, 2014). 과제에서 사용된 어휘목록은 Appendix 1에 제시하였다.

과제에서 사용된 그림은 $12 \mathrm{~cm} \times 15 \mathrm{~cm}$ 의 크기로 흰 종이에 검 은색 사인펜으로 윤곽만 그리고 코팅해서 사용하였다. 아동이 자 극 조건(범주, 형태, 주제)을 선택하는 과정에서 그림의 색깔이 단 서가 될 수 있으므로 윤곽만 그려서 사용하였다. 과제는 1 개의 표 본 자극과 3 개의 자극 조건으로 구성된 세트가 연습문항 2 개와 본 검사문항 20 개로 총 22 개이고, 자극 조건은 표본 자극과 범주적으 로 연관 있는 자극(범주 자극), 표본 자극과 형태적으로 유사한 자 극(형태 자극), 표본 자극과 주제적으로 연관 있는 자극(주제 자극)
으로 구성되어 있다. 자극 조건에서 범주 자극과 주제 자극 그림은 표본자극과 형태적으로 유사하지 않도록 제작하였다(Appendix 2).

\section{타당도}

과제에서 사용한 표본 자극과 표본 자극을 나타내는 비단어, 자 극 조건(범주, 형태, 주제)으로 구성된 총 22개 세트의 어휘와 그림 이 새로운 단어 습득 과정을 살펴보기 위한 도구로서 적합한지를 검증하기 위해 3 명의 전문가들에게 내용타당도에 관한 평가를 받 았다. 3 명의 전문가는 모두 언어병리학박사 학위소지자이며 1 급 언 어재활사자격증을 소지한 사람으로 하였다.

이들 전문가를 대상으로 과제에서 사용되는 비단어, 어휘, 그리 고 그림에 대한 타당도를 Likert 5 점 척도로 평가하게 한 결과, 비단 어의 내용타당도는 4.89 , 어휘의 내용타당도는 4.89 , 그림의 내용타 당도는 4.78 로 나타났다. 내용타당도 검증 과정에서 전문가들로부 터 제안된 내용을 토대로 2점 이하의 문항과 어휘를 연상하기 어려 운 그림, 연령에 맞지 않는 어휘와 그림, 그림의 크기, 연상되는 단어 가 있는 비단어를 제외하거나 수정하여 사용하였다. 과제는 2 차에 걸쳐 수정하였으며, 2 차 수정은 위 3 명의 전문가 중 1 명의 전문가와 함께 진행하였다.

\section{연구절차}

검사는 대상 아동이 다니는 어린이집과 유치원을 검사자가 직접 방문하여 실시하였고, 연구에 미칠 수 있는 영향을 최소화하기 위 해서 소음이 적은 방에서 검사자와 아동이 1:1로 진행하였다. 검사 자는 대상 아동이 다니는 어린이집과 유치원을 1 차로 방문해서 대 상자 선정을 위한 선별검사를 우선 진행하였고, 과제는 2 차로 방문 해서 실시하였다. 선별검사를 통해 집단을 선별한 후, 과제를 실시 하였다.

검사자와 아동은 책상에 마주보고 앉고 검사자는 아동에게 과 제의 절차에 대해 충분히 설명한 후, 먼저 연습문항을 실시하였다. 검사자는 아동에게 "선생님이 그림을 보여주고 질문할게요. 그러 면 $\bigcirc \bigcirc$ 가 질문을 듣고 잘 생각해서 세 가지 그림 중에 1 개를 선택 해주면 돼”라고 검사 절차에 대해 설명하였다. 검사자는 먼저 아동 에게 표본 자극을 보여 주고 나서, 이를 가리키면서 "자, 여기 봐요. 이것은 라고 해요."라고 표본 자극의 비단어를 말해주었다. 그 다음 세 가지의 자극 조건 그림을 동시에 보여주면서 "그런데 여기 또 '__ '가 있대. 자, '___를 찾아볼래요?”라고 질문하였다. 아동 이 표본 자극을 한 번 더 보여주기를 요청하면, 1 회에 한해 한 번 더 볼 수 있도록 기회를 제공하였다. 이와 같이 연습문항을 실시하고 검사자는 아동이 연습문항을 충분히 이해한 것을 확인한 후에 본 
검사문항을 실시하였으며, 검사 결과는 검사를 실시하면서 바로 기록하였다. 연습문항을 실시한 후 아동들에게 비교적 친숙한 그 림 카드들이 나열되었으므로, 아동들이 흥미를 느껴 과제 집중도 는 매우 높았으며, 검사에는 대체로 5-7분 정도 소요되었다.

\section{자료분석}

과제가 실시되는 동안 아동의 반응을 검사 기록지에 기록하였으 며, 아동이 선택한 자극에 1점을 부여하고 반응률은 백분율(\%)로 산출하였다. 즉, 단어의미 추론 반응률은 세 가지 자극 조건에서 아 동이 선택한 자극의 수를 연습문항을 제외한 전체 세트의 수(20세 트)로 나누고 100 을 곱하여 산출하였다.

\section{신뢰도}

과제 분석에 대한 신뢰도 검증을 위하여 본 연구의 연구자 1 명과 언어병리학석사 학위소지자 1 명 간의 검사자 간 신뢰도를 산출하 였다. 연구자는 검사자에게 검사 절차와 기록 및 채점 방법을 상세 히 설명한 후 전체 수집된 자료의 $30 \%$ 를 임의로 선정하여 채점하 도록 하였다. 그 결과 검사자 간 채점 신뢰도는 $98 \%$ 로 측정되었다.

\section{통계분석}

자극 조건에 따른 집단 간 단어의미 추론 반응률의 차이를 살펴 보기 위해 IBM SPSS Statistics version 21.0 프로그램을 사용하여 일원분산분석을 실시한 후 Scheffé 사후검정을 실시하였다. 또한 집단에서 각 자극 조건 간 단어의미 추론 반응률의 차이를 살펴보 기 위해 대응표본 $t$-검정을 실시하였다.

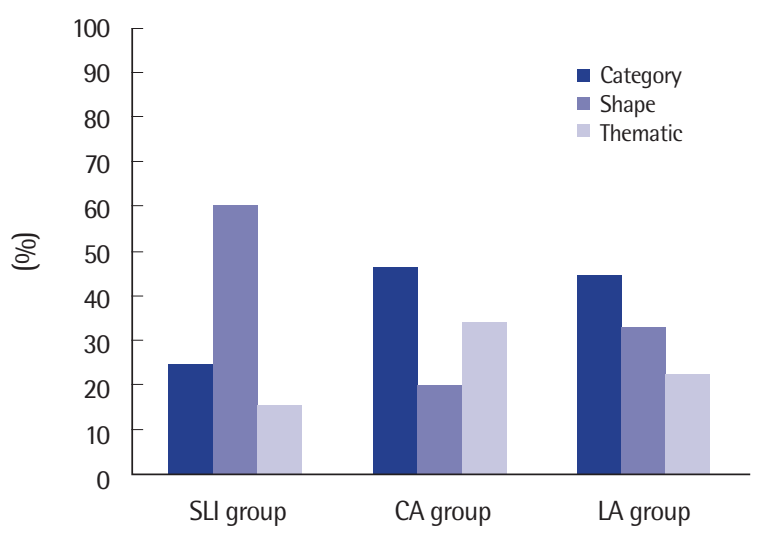

Figure 1. Semantic inference response rate of words among the three groups. $\mathrm{SLI}=$ children with specific language impairment; $C A=$ chronological agematched children; $L A=$ language age-matched children.

\section{연구결과}

\section{세 집단 간 단어의미 추론 반응률 비교}

과제에서 집단 간 단어의미 추론 반응률을 분석한 결과, 단순언 어장애 아동 집단은 형태 자극에서 높은 반응률을 보였지만, 생활 연령일치 아동 집단과 언어연령일치 아동 집단은 범주 자극에서 높 은 반응률을 보였다. 세 집단 간에 통계적으로 유의미한차이가 있는 지 알아보기 위해 일원분산분석을 실시한 결과, 범주 자극 $\left(F_{(2,48)}=\right.$ $6.407, p<.01)$, 형태 자극 $\left(F_{(2,48)}=21.485, p<.01\right)$, 주제 자극 $\left(F_{(2,48)}=\right.$ $4.001, p<.05$ )에서 집단 간 유의미한 차이가 있었다(Figure 1, Table 2). Scheffé 사후분석 결과, 범주 자극과 형태 자극에서 단순언어장 애 아동 집단과 생활연령일치 아동 집단 간 $(p<.05)$, 단순언어장애 아동 집단과 언어연령일치 아동 집단 간 $(p<.05)$ 유의미한 차이가 나타났다. 그러나 주제 자극에서는 단순언어장애 아동 집단과 생 활연령일치 아동 집단 $(p<.05)$ 사이에서만 유의미한 차이가 나타 났다.

Table 2. Comparison of semantic inference response rate of words among the three groups

\begin{tabular}{llccc}
\hline & $\begin{array}{c}\text { SLI group } \\
(\mathrm{N}=17)\end{array}$ & $\begin{array}{c}\text { CA group } \\
(\mathrm{N}=17)\end{array}$ & $\begin{array}{c}\text { LA group } \\
(\mathrm{N}=17)\end{array}$ & $F$ \\
\hline Category & $24.71(16.05)$ & $46.18(19.40)$ & $44.41(22.28)$ & $6.407^{* *}$ \\
Shape & $60.00(19.36)$ & $19.71(19.71)$ & $33.24(21.50)$ & $21.485^{* *}$ \\
Thematic & $15.29(9.91)$ & $34.12(24.06)$ & $22.35(21.80)$ & $4.001^{*}$ \\
Total of scores & $33.33(23.56)$ & $33.37(13.23)$ & $33.62(11.03)$ & \\
\hline
\end{tabular}

Values are presented as mean (SD).

$S L I=$ children with specific language impairment; $C A=$ chronological age-matched children; $\mathrm{LA}=$ language age-matched children.

${ }^{*} p<.05,{ }^{* *} p<.01$.

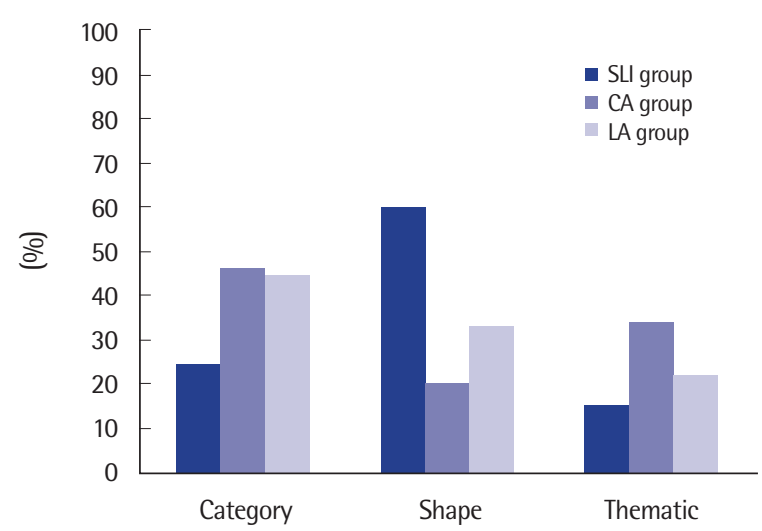

Figure 2. Semantic inference response rate of words in three groups. $S L I=$ children with specific language impairment; $C A=$ chronological agematched children; $\mathrm{LA}=$ language age-matched children. 


\section{세 집단 내 단어의미 추론 반응률 비교}

세 집단 내 단어의미 추론 반응률을 분석한 결과, 단순언어장애 아동 집단에서는 범주 자극과 형태 자극 간 $(t=-4.26, p<.01)$, 형태 자극과 주제 자극 간 $(t=7.02, p<.001)$ 에 유의미한 차이가 나타났으 며, 생활연령일치 아동 집단에서는 범주 자극과 형태 자극간 $(t=4.90$, $p<.001)$ 에 유의미한 차이가 나타났다. 그리고 언어연령일치 아동 집단에서는 범주 자극과 주제 자극 간 $(t=2.36, p<.05)$ 에 유의미한 차이가 나타났다(Figure 2). 결과를 자세히 살펴보면, 단순언어장 애 아동 집단은 형태>범주>주제 자극 순으로, 생활연령일치 아 동 집단은 범주> 주제>형태 자극 순으로, 언어연령일치 아동 집단 은 범주>형태>주제 자극 순으로 단어의미추론 반응률이 높았다.

\section{논의 및 결론}

본 연구에서는 단순언어장애 아동이 새로운 단어를 습득 과정 에서 범주, 형태, 그리고 주제라는 자극 조건이 단어의 의미를 추론 하는 데 어떠한 영향을 미치는지 일반 아동 집단과 비교하여 살펴 보고자 하였다. 연구 결과, 단순언어장애 아동 집단은 새로운 대상 의 의미를 추론하는 과정에서 주어진 자극이 형태일 때 좀 더 높은 반응률을 보였으며, 생활연령일치 아동 집단과 언어연령일치 아동 집단은 범주 자극에서 높은 반응률을 보였다. 이러한 결과는 통계 적으로도 유의미한 차이를 보였는데, 세 자극 조건 모두에서 집단 간 유의미한 차이가 있었다. 범주 자극과 형태 자극에서 단순언어 장애 아동 집단과 생활연령일치 아동 집단 간, 단순언어장애 아동 집단과 언어연령일치 아동 집단 간에 유의미한 차이가 나타났다. 하지만, 주제 자극에서는 단순언어장애 아동 집단과 생활연령일치 아동 집단 사이에서만 유의미한 차이가 나타났다.

좀 더 구체적으로 집단 간 자극 조건에 따른 단어의미 추론 반응 률을 살펴본 결과, 범주 자극에서 단순언어장애 집단과 생활연령 일치 아동 집단, 단순언어장애 아동 집단과 언어연령일치 아동 집 단 간에 유의미한 차이가 나타났다. 이와 같은 결과는 단순언어장 애 아동이 일반 아동과 달리 새로운 대상을 범주로 분류하여 인식 하는 것에 어려움이 있음을 보여준다. 단어의 의미를 습득하는 과 정에서 범주화는 의미 추론의 가장 기초 단계라고 할 수 있는데, 단 어 자체가 범주에 대한 이름이므로 아동은 범주를 발달시켜야만 비로소 단어를 학습할 수 있게 되기 때문이다(Ludden, 2015). 본 연 구의 이러한 결과는 단순언어장애 아동들이 보이는 단어의미 추론 의 어려움이 기본적인 범주화의 결함도 한 가지 원인으로 작용할 수 있었음을 가정할 수 있게 한다. 이는 단순언어장애 아동의 특성 을 파악하고 중재하는 데 있어서 대상 간의 공통적인 속성에 따라
체계적으로 분류하는 범주화를 포함하여야 한다는 것을 시사한다. 일반적으로 언어 습득은 청각적 메시지와 맥락 정보의 활용과 더불어, 이미 저장되어 있는 세상사 지식과 단어 지식으로부터 의 미를 추론해야 하는 역동적인 과정들이다. 하지만, 단순언어장애 아동은 이러한 다양한 맥락 단서로부터 얻을 수 있는 유용한 정보 들을 역동적으로 사용하지 않는 것으로 보인다. 이들은 일반적으 로 말이나 비언어적 단서를 통해 일련의 사건들이 제시될 때, 이러 한 연속적인 단서 정보들로부터 사건에 대한 통합적 표상을 형성하 는 데 어려움이 있다(Owens, 2013). 실제로, 일반 아동들이 어휘를 습득하는 과정은 무수하게 반복되는 언어적 입력을 통해 의미를 추론한 결과이며, 성인들의 직접적인 지시나 촉진이 없이도 이루어 지는 과정이지만 단순언어장애 아동들에게 이러한 과정은 구체적 인 사건과 사물로 제한될 수밖에 없다. 즉, 매우 제한적인 역동적 정 보처리 전략을 사용하는 단순언어장애 아동은 어휘 성장이 매우 어려울 것이다. Alt, Plante와 Creusere (2004)에 따르면, 단순언어 장애 아동은 물리적 자질(색, 모양, 크기)이나 주제적 요소(게임에 서 던지기, 치기, 잡기), 인과관계(행동을 일으킨 사람, 받은 사람 또 는 사물)와 같은 사물과 행동의 의미적 양상들을 적게 인지하며, 일반 아동과 달리 크기, 형태, 색, 양, 질 등과 같은 개념 표현 단어들 을 이해하거나 산출하는 데 어려움이 있음을 보고하였다. 본 연구 에서는 단순언어장애 아동 집단이 일반 아동에 비해 새로운 단어 의 의미를 추론할 때 단순하게 드러나는 대상의 형태와 같은 지각 적인 유사성에 초점을 두는 것으로 나타났다. 이는 형태와 같은 지 각적 특성이 학령전 단순언어장애 아동에게서 단어를 습득하는 중요한 기제로 작용하고 있음을 말한다. 이러한 결과는 Kim과 Lee (1996)의 연구와도 비교해 볼 필요가 있는데, 이들은 3 세와 5 세 일 반 아동들이 범주적인 관계에 대한 기본적인 지식을 가지고는 있지 만 새로운 단어의 의미를 추론할 때 이보다 먼저 형태적 유사성을 사용하고 있다고 보고하였다. 즉, 본 연구의 단순언어장애 아동들 은 단어의 의미 습득 과정에서 훨씬 더 나이 어린 아동들의 특성에 근거한 추론 방식을 보여주고 있는 것이다. 본 연구에서 언어연령일 치 집단의 경우 Kim과 Lee (1996)의 연구와 달리 형태적 유사성에 대한 선호를 보이지 않았다. 이는 평균 생활연령이 68개월인 다른 집단과 달리, 언어연령일치 집단이 52.76개월인 것에서도 알 수 있 듯이 이들이 초기 의미 추론 방식에서 좀 더 나이 든 아이로의 발달 적 이행 과정에 있는 것으로 해석할 수 있었다.

반면, 주제 자극에서는 단순언어장애 아동 집단과 생활연령일치 아동 집단 간에서만 유의미한 차이가 나타났다. 이와 관련해서 Kim (2007)의 연구에서도 3세와 5세 아동의 경우, 주제적 범주화의 발 달 이후 분류적 범주화의 발달이 두드러짐을 보였다고 한다. 본 연 
구에서는 생활연령일치 아동들이 가장 나이 든 아동들이었으므 로 발달적으로 주제 자극을 단어의미 추론에 활용할 수 있었던 것 으로 보인다. 이처럼 단순언어장애 아동이 대상 간의 주제적 관계 에 대한 이해와 범주화 능력에 모두 어려움이 있는 것을 고려할 때 이들의 중재 시에는 대상과 사건들 간의 상호작용적, 보완적 관계 와 더불어 각 사물을 범주화하는 것에 대한 보다 구체적인 자극이 필요한 것으로 볼 수 있다.

본 연구에서 단순언어장애 아동 집단은 형태, 범주, 주제 자극 순 으로 단어의미를 추론하였으며, 생활연령일치 아동 집단은 범주, 주제, 형태 자극 순이었고, 언어연령일치 아동 집단은 범주, 형태, 주 제 자극 순으로 단어의미를 추론하였다. 단순언어장애 아동이 일 반 아동과 달리 주제나 범주에 따른 단어의미 추론에 어려움을 보 였으므로 이들이 발달적으로 단어의미 추론의 초기 단계에 머무 르고 있는 수준으로 해석할 수도 있겠지만, 이러한 형태 편파가 오 히려 이들 아동 고유의 처리 양식인지에 대해서는 좀 더 면밀히 분 석해 볼 필요가 있을 것이다

학령전 단순언어장애 아동들이 보이는 의미론 습득의 어려움은 이후 학령기의 언어 학습 부진이나, 읽기와쓰기를 포함한 문해력의 어려움으로 이어지기도 한다. 읽기 관련 연구들에서는 대상과 공 간, 언어로 이뤼지는 인지양식의 관점에서 읽기결함 해석을 시도하 고 있다(West, 2009). 특히, 이러한 인지양식은 작업기억과도 관련 이 있어 언어의 이해와 표현에 보다 직접적으로 관여하게 된다는 연 구들로 이어지고 있다(Shin \& Kim, 2013). 따라서, 단순언어장애 아 동을 포함해 학습 부진이나 읽기에 어려움을 보이는 아동의 경우, 그들만의 특정 인지양식에서의 강점을 파악하는 것이 언어 중재와 교육을 위한 무엇보다 필요할 것으로 보인다. 본 연구에서 학령전 단순언어장애 아동이 자극의 형태에 의존하는 특성을 보이고 있었 던 반면, Collisson 등(2015)의 연구에서 5 세 단순언어장애 아동들 은 형태, 색깔, 재질 단서를 제시했을 때, 형태에 기반한 단어의미 추 론에 여전히 취약함을 보여주었다. 이러한 차이는 본 연구와 달리 친숙하지 않은 3 차원의 새로운 대상에 대한 의미 추론 과제였고, 나 머지 선택 역시 색깔이나 재질 단서라는 차이가 있어 직접적인 비교 에는 어려움이 있다. 무엇보다 중요한 것은 본 연구의 방법과 절차만 으로는 단순언어장애 아동의 형태 편파라는 이러한 특성이 단어 습득 과정에서 단지 일반 아동들과 유사한 발달 단계로의 진입을 위한 발달적 특성인지, 또는 단순언어장애 아동의 인지양식에 근거 한 고유의 특성인지를 밝히기에는 어려움이 있었다는 점이다. 따라 서, 추후 연구에서는 7세 이후 초기 학령기에 이르기까지의 단순언 어장애 아동들을 대상으로 단어의미 추론의 발달적 특성을 살펴 봄과 동시에, 이들의 인지양식을 분류하여 자극 조건에 따른 이들
아동들의 고유한 의미 습득 특성을 밝혀볼 필요가 있을 것이다.

본 연구는 그동안 일반 아동을 대상으로 이뤄지던 자극 조건에 따른 단어의미 추론 연구 방법을 활용하여 단순언어장애 아동의 자극 조건 선호를 살펴보았다는 데 의의가 있다. 단순언어장애 아 동들이 빠른 연결 전략 사용의 결함으로 인해 이후 단어 습득과 인 출 전반에 걸쳐 어려움을 겪게 되는 발달 특성에 대해서는 이미 많 은 연구들을 통해 밝혀졌음에도 불구하고, 국내에서 이들 아동의 단어의미 추론 특성을 보다 구체적으로 살펴보는 연구 접근은 매 우 제한적인 상황에서 본 연구의 결과는 매우 고무적이다.

하지만, 본 연구는 과제를 실시하는 과정에서 하나의 표본 자극 과 함께 주어지는 비단어를 들은 다음, 아동이 세 가지 자극 중 하 나를 무조건 선택해야 하는 강제 선택과제였으므로 그밖의 자극이 나 무관련 자극을 선택에 포함하는 등 우연 확률을 최소화하기 위 한 추가적인 실험 설계가 필요했을 것으로 보인다. 또한, 본 연구의 실험 절차와 관련해 과제에서 사용한 20 개의 세트가 아동의 의미 추론 과정과 능력을 보다 구체적으로 살피기에는 한계가 있었던 것 으로 보인다. 그리고 자극 조건 과제에서 사용된 어휘목록을 명사 에 초점을 두어 제작하였으나 후속연구에서는 학령 전 아동의 전 반적 어휘발달을 고려하여 동사, 형용사 등의 다른 품사까지 포함 해서 살펴볼 필요가 있을 것이다. 또한 밤-밤송이 같은 단어에서도 볼 수 있듯이 단어들이 주제 뿐만 아니라 음운적 유사성도 있으므 로 이에 따른 아동의 선택과 더불어 생물과 무생물 요인을 함께 고 려할 필요도 있었을 것이다.

본 연구는 생활연령이 평균 5 세 8 개월, 언어연령이 평균 4 세 3 개 월인 단순언어장애 아동 집단과 생활연령을 일치시킨 아동 집단, 그리고 언어연령을 일치시킨 아동 집단을 대상으로 하였다. 그러나 단순언어장애 아동의 발달을 고려할 때, 후속연구에서는 이보다 높은 연령의 단순언어장애 아동을 대상으로 범주, 형태, 주제라는 자극의 조건이 어떠한 양상으로 변화하는지 살펴보는 것도 의미가 있을 것이다.

\section{REFERENCES}

Alt, M., Plante, E., \& Creusere, M. (2004). Semantic features in fast-mapping: performance of preschoolers with specific language impairment versus preschoolers with normal language. Journal of Speech, Language, and Hearing Research, 47, 407-420.

Bloom, P. (2001). Précis of how children learn the meanings of words. Behavioral and Brain Sciences, 24, 1095-1103.

Botting, N., \& Adams, C. (2005). Semantic and inferencing abilities in chil- 
dren with communication disorders. International Journal of Language and Communication Disorders, 40, 49-66.

Cha, J. E., Kim, J. M., Kim, S. J., Yoon, M. S., \& Chang, M. S. (2014). Substantives in the vocabulary of typically developing young children. Communication Sciences \& Disorders, 19, 430-446.

Collisson, B. A., Grela, B., Spaulding, T., Rueckl, J. G., \& Magnuson, J. S. (2015). Individual differences in the shape bias in preschool children with specific language impairment and typical language development: theoretical and clinical implications. Developmental Science, 18, 373-388.

Golinkoff, R. M., Shuff-Bailey, M., Olguin, R., \& Ruan, W. (1995). Young children extend novel words at the basic level: evidence for the principle of categorical scope. Developmental Psychology, 31, 494-507.

Gray, S. (2005). Word learning by preschoolers with specific language impairment: effect of phonological or semantic cues. Journal of Speech, Language, and Hearing Research, 48, 1452-1467.

Imai, M., Gentner, D., \& Uchida, N. (1994). Children's theories of word meaning: the role of shape similarity in early acquisition. Cognitive Development, 9, 45-75.

Isoaho, P., Kauppila, T., \& Launonen, K. (2016). Specific language impairment (SLI) and reading development in early school years. Child Language Teaching and Therapy, 32, 147-157.

Jackson, E., Leitao, S., \& Claessen, M. (2015). The relationship between phonological short-term memory, receptive vocabulary, and fast mapping in children with specific language impairment. International Journal of Language \& Communication Disorders. doi:10.1111/1460-6984.12185

Jung, K. H., Pae, S., \& Kim, G. (2006). The early phonological development of Korean children. Korean Journal of Communication \& Disorders, 11, $1-15$.

Kim, J. H. (2007). The development of categorization in 3- to 9-year old Korean children (Master's thesis). Dankook University, Yongin, Korea.

Kim, K. (2001). Selection of total vocabulary for each grade in Korean. Seoul: Korean Language Education Research Institute.

Kim, M. R. N., Hwang, M. A., \& Lim, J. A. (2012). Drawing inferences from the presuppositions of sentences in children with specific language impairment (SLI). Journal of Speech and Hearing Disorder, 21, 1-15.

Kim, S. S. (2004). Functional working memory and word learning of Korean children with specific language impairment. Korean Journal of Communication \& Disorders, 9, 78-99.

Kim, Y. J., \& Lee, H. J. (1996). The role of shape similarity in children's inferences of word meaning. Korean Journal of Psychology: Developmental, 9,
15-29.

Kim, Y. T., Sung, T. J., \& Lee, Y. (2003). Preschool Receptive-Expressive Language Scale (PRES). Seoul: Seoul Community Rehabilitation Center.

Lee, E. Y., \& Ha, J. W. (2015). Semantic representation in children with specific language impairment. Communication Sciences \& Disorders, 20, 277289.

Lee, H. R., Chang, Y. K., Choi, Y. L., \& Lee, S. B. (2009). Lexical acquisition of Korean infants: characteristics of early expressive vocabulary. Journal of Speech \& Hearing Disorders, 18, 65-80.

Lee, J. H., \& Lee, S. B. (2000). Specific-language-impaired children's wordlearning strategy. Korean Journal of Psychology: Development, 13, 159-172.

Lee, S., \& Lee, H. R. (2006). Lexical ambiguity comprehension of Korean children with specific language impairments. Korean Journal of Communication \& Disorders, 11, 14-29.

Lee, Y. K. (2005). A semantic organization of the words of children with specific language impairment. Korean Journal of Communication \& Disorders, $10,43-57$.

Lee, Y., \& Kim, Y. T. (2003). Word (noun and verb) production in children with specific language impairment. Korean Journal of Communication \& Disorders, 8, 1-19.

Leonard, L. B. (2014). Children with specific language impairment (2nd ed.). Cambridge, MA: MIT Press.

Ludden, D. (2015). The psychology of language: an integrated approach. Thousand Oaks, CA: Sage Publications.

Marinellie, S. A., \& Johnson, C. J. (2002). Definitional skill in school-age children with specific language impairment. Journal of Communication Disorders, 35, 241-259.

McGregor, K. K., \& Appel, A. (2002). On the relation between mental representation and naming in a child with specific language impairment. Clinical Linguistics \& Phonetics, 16, 1-20.

Owens, R. E. (2013). Language disorders: a functional approach to assessment and intervention. Boston, MA: Pearson.

Park, H. W., Kwak, K. J., \& Park, K. B. (1997). Korean-Wechsler Preschool and Primary Scale of Intelligence (K-WPPSI). Seoul: Seoul Community Rehabilitation Center.

Rice, M. L. (1990). Preschooler's QUIL: quick incidental learning of words. In G. Conti-Ramsden \& C. E. Snow (Eds.), Children's language (pp. 185210). Hillsdale, NJ: Erlbaum.

Rice, M. L., Buhr, J., \& Oetting, J. B. (1992). Specific-language-impaired children's quick incidental learning of words: the effect of a pause. Journal of 
Ji Won An, et al. • Word Learning according to Stimulus Conditions of Korean Children with SLI

Speech, Language, and Hearing Research, 35, 1040-1048.

Rice, M. L., Cleave, P. L., \& Oetting, J. B. (2000). The use of syntactic cues in lexical acquisition by children with SLI. Journal of Speech, Language, and Hearing Research, 43, 582-594.

Saalbach, H., \& Schalk, L. (2011). Preschoolers' novel noun extensions: shape in spite of knowing better. Frontiers in Psychology, 2, 317.

Shin, G. H., \& Kim, C. B. (2013). Individual differences in performance on working memory tasks according to object, spatial, and verbal cognitive styles. Korean Journal of Cognitive and Biological Psychology, 25, 539-563.

Sim, H., \& Ha, S. (2014). Comparison of phonological development between typically developing children and late talking children aged 18-30 months. Communication Sciences \& Disorders, 19, 99-112.
Sobel, D. M., Sedivy, J., Buchanan, D. W., \& Hennessy, R. (2012). Speaker reliability in preschoolers' inferences about the meanings of novel words. Journal of Child Language, 39, 90-104.

Stark, R. E., \& Tallal, P. (1981). Selection of children with specific language deficits. Journal of Speech and Hearing Disorders, 46, 114-122.

West, T. G. (2009). In the mind's eye: Creative visual thinkers, gifted dyslexics, and the rise of visual technologies (2nd ed.). Amherst, NY: Prometheus Books.

Whitehouse, A. J., Line, E. A., Watt, H. J., \& Bishop, D. V. (2009). Qualitative aspects of developmental language impairment relate to language and literacy outcome in adulthood. International Journal of Language \& Communication Disorders, 44, 489-510. 
Appendix 1. List of words used in the stimulus conditions

\begin{tabular}{|c|c|c|c|c|}
\hline Set & 표본 자극(비단어) & 범주 자극 & 형태 자극 & 주제 자극 \\
\hline 연습1 & 사과(디구) & 포도 & 풍선 & 칼 \\
\hline 연습2 & 나비(따우) & 벌 & 리본 & 吕 \\
\hline 1 & 바나나(너버) & 파인애플 & 달 & 원숭이 \\
\hline 2 & 당근(빠드) & 감자 & 못 & 토끼 \\
\hline 3 & 양파(미내) & 가지 & 단추 & 프라이팬 \\
\hline 4 & 밤(나끼) & 호두 & 물방울 & 밤송이 \\
\hline 5 & 고추(브때) & 호박 & 우산 & 불 \\
\hline 6 & 오이(쿠도) & 피망 & 방망이 & 밭 \\
\hline 7 & 악어(태브) & 하마 & 가위 & 늪지대 \\
\hline 8 & 잠자리(토리) & 무당벌레 & 비행기 & 잠자리채 \\
\hline 9 & 뱀(깨도) & 거북이 & 목도리 & 숲 \\
\hline 10 & 오징어(어거) & 조개 & 고무장갑 & 그물 \\
\hline 11 & 불가사리(뿌느) & 소라 & 별 & 바다 \\
\hline 12 & 금붕어(리꺼) & 열대어 & 우주선 & 어항 \\
\hline 13 & 모자(개로) & 썬캡 & 케이크 & 머리 \\
\hline 14 & 튜브(라모) & 공 & 도넛 & 수영복 \\
\hline 15 & 목걸이(보코) & 반지 & 거울 & 여자 \\
\hline 16 & 구두(이푸) & 운동화 & 미끄럼틀 & 발 \\
\hline 17 & 바지(뻐매) & 치마 & 집게 & 옷장 \\
\hline 18 & 숟가락(뚜아) & 포크 & 막대사탕 & 밥 \\
\hline 19 & 칫솔(파구) & 치약 & 빗 & 이 \\
\hline 20 & 안경(프카) & 손목시계 & 땅콩 & 눈 \\
\hline
\end{tabular}

Appendix 2. Example of stimulus conditions
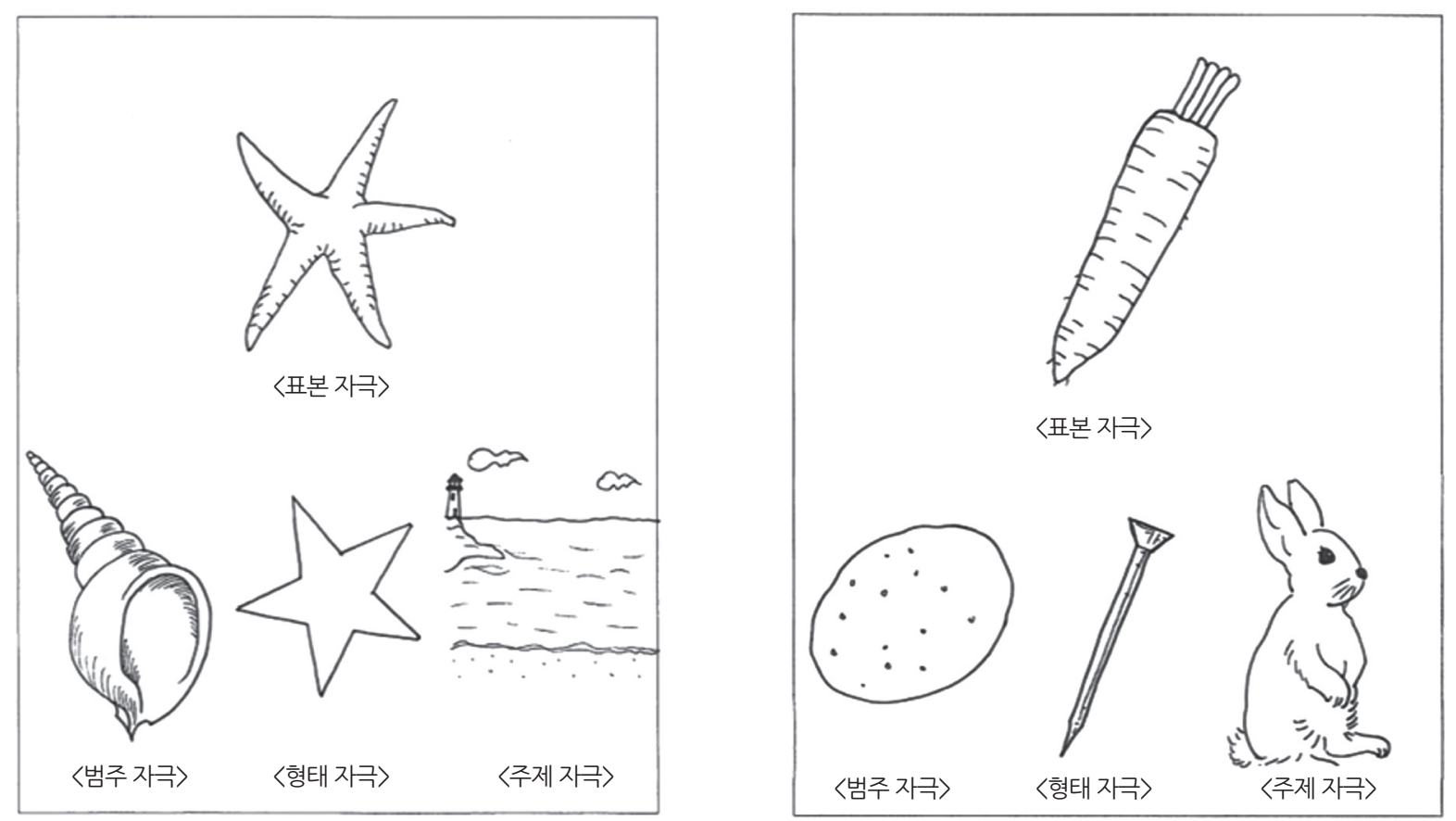


\section{국문초록}

\section{학령전 단순언어장애 아동의 자극 조건에 따른 단어의미 추론 안지원 $\cdot$ 이희란 ${ }^{2}$ \\ '부산가톨릭대학교 대학원 언어청각치료학과, ${ }^{2}$ 부산가톨릭대학교 언어청각치료학과}

배경 및 목적: 본 연구에서는 단순언어장애 아동이 새로운 단어를 습득하는 과정에서 범주, 형태, 그리고 주제라는 자극 조건이 단어 의 의미를 추론하는 데 어떠한 영향을 미치는지 살펴보고자 하였다. 방법: 대상자는 4-6세 단순언어장애 아동 17명, 이들과 생활연령 을 일치시킨 일반 아동 17 명, 언어연령을 일치시킨 일반 아동 17 명이었다. 아동들에게 친숙한 사물에 대한 이름으로 자극 조건별로 새 로운 단어를 제시했을 때, 이들이 선택한 의미 추론 방식을 집단과 자극 조건 간의 반응률 차이로 살펴보았다. 결과: 집단 간 자극 조건 에 따른 단어의미 추론 반응률의 차이를 살펴본 결과, 범주, 형태, 주제 자극에서 집단 간에 유의미한 차이를 보였다. 집단 내 자극 조건 간 단어의미 추론 반응률에서 단순언어장애 집단은 형태, 범주, 주제 자극 순이었으며, 생활연령일치 집단은 범주, 주제, 형태 자극, 그리 고 언어연령일치 집단은 범주, 형태, 주제 자극 순으로 단어의미 추론 반응률이 높았다. 논의 및 결론: 본 연구에서는 학령전 단순언어 장애 아동이 단어의미를 추론할 때 보다 어린 연령의 일반 아동들과 유사한 방식으로 자극의 형태에 의존하는 특성을 보이고 있음을 확인하였다. 또한, 이러한 결과가 단순언어장애 아동의 발달적 특성인지 또는 이들만의 인지양식에 근거한 고유의 특성인지를 밝히기 위한 후속 연구가 필요함을 논의하였다.

핵심어: 단순언어장애, 단어의미 습득, 추론, 범주, 형태, 주제

본 연구는 제1저자의 석사학위논문을 수정하여 작성하였음.

\section{참고문헌}

김광해(2001). 한국어의 등급별 총어휘 선정. 서울: 서울대학교 국어교육연구소.

김미리내, 황민아, 임종아(2012). 단순언어장애아동의 전제의미 추론. 언어치료연구, 21, 1-15.

김성수(2004). 단순언어장애 아동의 기능적 작업기억과 낱말 습득 특성. 언어청각장애연구, 9, 78-99.

김영태, 성태제, 이윤경(2003). 취학전 아동의 수용언어 및 표현언어 발달척도(PRES). 서울: 서울 장애인종합복지관.

김유정, 이현진(1996). 아동의 단어의미 추론에서 형태 유사성의 역할. 한국심리학회지: 발달, 9, 15-29.

김재홍(2007). 일반 아동의 의미 범주화 발달에 관한 연구: $3,5,7,9$ 세를 중심으로. 단국대학교 대학원 석사학위논문.

박혜원, 곽금주, 박광배(1997). 한국-웩슬러 유아지능검사(K-WPPSI). 서울: 도서출판 특수교육.

신경희, 김초복(2013). 대상, 공간 및 언어 인지양식에 따른 작업기억 수행의 개인차. 한국심리학회지: 인지 및 생물, 25, 539-563.

심혜림, 하승희(2014). 18-30개월 말 늦은 아동과 일반 아동의 음운 발달 비교. 언어청각장애연구, 19, 99-112.

이승복, 이희란(2006). 단순언어장애아동의 어휘적 모호성 이해. 언어청각장애연구, 11, 14-29.

이윤경(2005). 단순언어장애아동의 낱말 의미구조화 특성. 언어청각장애연구, 10,43-57.

이윤경, 김영태(2003). 단순언어장애 아동들의 낱말산출 능력: 명사와 동사를 중심으로. 언어청각장애연구, 8, 1-19.

이은영, 하지완(2015). 단순언어장애 아동과 일반 아동의 의미표상 비교. 언어청각장애연구, 20, 277-289.

이주희, 이승복(2000). 특수언어장애(SLI) 어린이의 어휘 획득 전략. 한국심리학회지: 발달, 13, 159-172.

이희란, 장유경, 최유리, 이승복(2009). 한국아동의 어휘습득 언어치료연구, 18, 65-80.

정경희, 배소영, 김기숙(2006). 12, 18, 24개월 영유아의 음운발달 특성. 언어청각장애연구, 11, 1-15.

차재은, 김정미, 김수진, 윤미선, 장문수(2014). 2-5세 일반 아동의 어휘 발달: 체언. 언어청각장애연구, 19, 430-446. 